\title{
Who wears the Hijab? Predictors of Veiling in Greater Jakarta
}

\author{
Ariane Utomo \\ School of Geography, The University of Melbourne \\ Ariane.utomo@unimelb.edu.au \\ Anna Reimondos, \\ School of Demography, The Australian National University \\ Anna.reimondos@anu.edu.au \\ Peter McDonald \\ Melbourne School of Population and Global Health, The University of Melbourne \\ Mcdonald.p@unimelb.edu.au \\ Iwu Utomo \\ School of Demography, The Australian National University \\ Iwu.utomo@anu.edu.au \\ Terence Hull \\ School of Demography, The Australian National University \\ Terry.hull@anu.edu.au
}

This is a postprint version of the article. The version here has been peer reviewed but not copy-edited.

Published version can be found here:

https://link.springer.com/article/10.1007/s13644-018-0345-6

Please cite as: Utomo, A., Reimondos, A., McDonald, P., Utomo, I., \& Hull, T. (2018). Who Wears the Hijab? Predictors of Veiling in Greater Jakarta. Review of Religious Research, 60(4), 477-501.

https://doi.org/10.1007/s13644-018-0345-6 


\begin{abstract}
Indonesia is home to the world's largest Muslim population. In contrast to much of the Middle East, veiling in Indonesia is neither a deeply rooted cultural practice, nor it is universally practised among Muslim women. Just 30 years ago it was rare to see an Indonesian woman wearing a hijab or veil. Today, veiling has become a relatively common practice, particularly among middle-class Muslim women living in urban areas. Although statistics on the prevalence of veiling are scant, the fact of growing use of headscarves is widely accepted in the literature. This paper examines sociodemographic correlates of veiling among young women in the capital region of Indonesia. We analyse a representative sample of 1443 Muslim women aged 20-34 in Greater Jakarta in 2010. About $26 \%$ of the women surveyed wore the veil. We found a moderately strong association between veiling and other measures of religiosity, including self-reported subjective religiosity and frequency of reading religious texts. Our multivariate analysis suggests a positive association between educational attainment and the likelihood of veiling among young Muslim women. In discussing these findings, we draw upon the qualitative component of our study and the literature on Islam, gender, and modernity in Indonesia. The paper highlights the difficulty encountered examining the practice of veiling as a binary choice, and as a measure of religiosity.
\end{abstract}

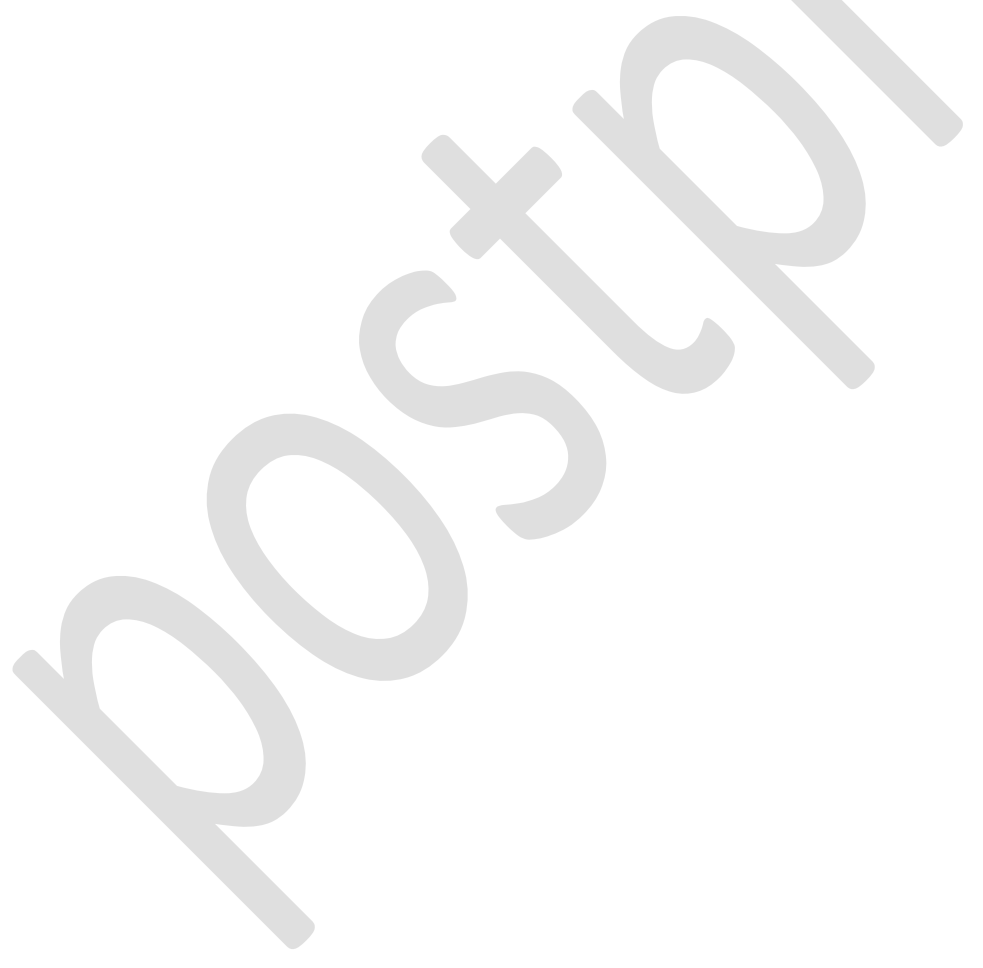




\section{INTRODUCTION}

Indonesia is home to the world's largest Muslim population. The latest population census indicates that Islam is the nominated religion for over 200 million residents, or 87 per cent of Indonesia's 238 million population (BPS-Statistics Indonesia, 2013). In contrast to much of the Middle East, veiling in Indonesia is neither a deeply rooted cultural practice, nor is it universally practised among Muslim women (Brenner, 1996; Smith-Hefner, 2007; Candraningrum, 2013; Feillard and van Doorn-Harder, 2013). Just 30 years ago, it was rare to see an Indonesian Muslim woman wearing a hijab or veil. However, against the background of a renewed vigour of Islam following the political Reforms in the late 1990s, hijab-wearing women are noticeable in streets and the popular media and across all facets of the public sphere (Warburton, 2006).

In the period following the abrupt ending of 32 years of Suharto's authoritarian New Order regime in 1998, there has been a rising scholarly interest in examining the dress practices of Muslim women in Indonesia and particularly the adoption of various kinds of head and face coverings (Brenner, 1996; Candraningrum, 2013; Hamdani, 2008; Jones, 2007; Nisa, 2012; Parker, 2008; Smith-Hefner, 2007; Jefferies 2011; Wagner, Sen, Permanadeli, \& Howarth, 2012, Rahmaniyah 2013). The focal point in academic discussions on veiling in the Reform Era rests on explaining the interactions between its growing pervasiveness, particularly among the young educated urban population, the rise of Islamic piety, the questions of identity and agency, and the broader context of socio-political change. So far, however, there has been little research that examines the sociodemographic correlates of veiling or estimates its statistical prevalence in the general Muslim population.

As with other measures of religiosity, any attempt to quantify and measure veiling is challenging. To begin with, we acknowledge that it is difficult to conceptualise the practice of veiling as a simple binary choice. The literature on women and Islam in Indonesia highlights the complexities in articulating the meaning of and the motivation behind putting on a veil (Brenner, 1996; Hamdani, 2008; Parker, 2008; Rinaldo, 2008).

In many parts of urban Indonesia, where Muslims are the overwhelming majority, but veiling is not the norm, the practice of veiling represents multiple rays of a spectrum including styles, modesty, frequency, consistency, and intensity among others (Amrullah, 2008; Jones, 2007). At the very least, the general intention of veiling is to cover up the aurat - an Arabic term used in the Indonesian context to refer to the parts of a woman's body that should not be seen in public. Individual and group interpretations of aurat (Ind: batas aurat) vary widely. On the liberal end, a combination of using a scarf as a loose head cover with a long-sleeved top, tight jeans, and opentoe high heels on public outings, is enough to identify a woman as being veiled (Ind: memakai jilbab, berhijab). On the conservative end, while the practice is relatively rare, there are women in complete chador (Nisa, 2012) covering their whole body in loose material, at times including the masking of their faces. The literature suggests that it is difficult to assert that the intensity of veiling runs parallel to other conventional measures of religiosity.

Bearing these conceptual constraints in mind, we take a statistical approach to understand the phenomenon of veiling in Greater Jakarta. This teeming metropolis encompasses Indonesia's capital city of Jakarta and its surrounding satellite cities of Tangerang, Bogor, Depok and Bekasi, home to an estimated population of 28 million in 2010 (BPS-Statistics Indonesia, 2013). We focus our analysis on a binary variable of whether a Muslim woman is veiled or not (in any form) using 
a representative sample of 1,443 Muslim women aged 20-34 residing in Greater Jakarta in 2010. Our paper addresses the following questions. First, what is the prevalence of veiling among young women in Greater Jakarta? Second, what is the relationship between veiling and other self-reported measures of religiosity? Third, what are the socio-demographic correlates of veiling?

Addressing these research questions contributes to the bourgeoning scholarship on the contemporary Islamic revival. In particular, we seek to understand how the perceived increase in the uptake of veiling in urban Indonesia helps modify convictions about the assumed parallel trends of modernity and secularisation. We structure our paper around three hypotheses:

First is the proposition that the rise in veiling signifies a growth of personal or internalised religious identity among young adults in Jakarta. Here, we look at the relation between the practice of veiling and other measures of religiosity such as subjective religiosity, frequency of reading Islamic texts, membership of a religious organisation, and parental religiosity. We found a moderate association between measures of religiosity and veiling.

Second, we test the view that the increased uptake of veiling represents a society-wide trend towards religion, representing anti-secularisation and anti-Western sentiments. In other words, is the act of veiling an expression of religiosity largely driven by a sense of longing for a distinct, non-Western identity? To examine this hypothesis, we test the association between veiling and some crude measures of social attitudes and political views. We did not find significantly large differences in the attitudes and world views of women with and without the veil. But the proportion of women voting for an Islamic party in the 2009 general election was higher among veiled than non-veiled respondents.

The last proposition hinges on the bourgeoning discussions of Islam in contemporary Indonesia that see veiling in the context of the rising middle-class and the associated emergence of 'pious' consumption (Fealy, 2008; Heryanto, 2008; Jones, 2007; Jones, 2010). To test this proposition, we use education levels as a proxy of socio-economic status and investigate how the likelihood of veiling varies by women's education levels. We found a positive and significant association between veiling and education level. There is also a strong positive relationship between veiling and father's education level.

We begin this paper by giving an overview of veiling in contemporary Indonesia. Here, we note how veiling has shifted from being a marginal practice to a fashionable one. We further outline the literature on the drivers of the increased popularity of veiling in Indonesia, and how the phenomenon of veiling in contemporary Indonesia can be understood in the global context. Section 3 details our approach, data and methods. Section 4 presents our results organised by the three hypotheses of interest as described above. We highlight the limitations of conceptualising veiling as a binary choice in our survey results by drawing upon qualitative findings from our study.

\section{BACKGROUND}

\section{Veiling: The shift from being a marginal to a fashionable practice}

In previous generations, few Muslim Indonesian women wore headscarfs, and those who did tended to be older members of the traditional rural class or the Muslim merchant class (SmithHefner 2007). Suharto’s New Order government (1966-1998) is renowned for its attempt to 
marginalise Islamic political forces (see Hasan, 2009). Veiling was seen as being associated with forms of Islamic forces that could destabilize the nation (Brenner, 1996). The push for stronger public institutions and Islamic collective identity in Indonesia has been brewing since the mid1970s (Hasan, 2009: 231). But, coinciding with a global wave of Islamic revival, the fall of the New Order in 1998, and the democratic reform that ensued offered an unprecedented opportunity for the rise of many facets and elements of Islam. This included increasing calls for the implementation of Sharia by-laws, the proliferation of Islamic banking and business, and the development of an Islamic pop culture (see Heryanto, 2011, Fealy and White, 2008). Some scholars have pointed to the rising popularity of veiling as a marker of the rise of public Islam in post New Order Indonesia (see Hasan, 2009).

The practice of veiling became more widespread following the fall of the New Order and the subsequent onset of the reform period (Ind: Reformasi) in 1998 (Jones, 2007; Warburton, 2006). During the 1980s, wearing the veil was seen as a militant action, practised mainly by a minority of religious activists, particularly students at universities, who were calling for reform of the New Order regime (Candradingrum 2013). In 1985, there was some controversy as the government prohibited some female students from wearing the veil in school, arguing that it was against the school uniform regulations.

A study of veiling in Java conducted prior to the onset of the reforms noted that although there was an increasing adoption, or rather 'conversion', for veiling among Javanese women since the 1970s, it remained a 'marginal practice' and veiled women were often met with suspicion (SmithHefner, 2007, p. 675). Smith-Hefner's subsequent field studies in the nation's second largest state university located in Yogyakarta suggest that the prevalence of veiling among female Muslim students had risen from less than 3 per cent in the late 1970s, to over 60 per cent in 1999-2002. Although there are no statistics to support claims of the increasing popularity of veiling in the Muslim female population as a whole, such assertions are widely accepted on the basis that veiling has become socially visible.

Following the Reforms, veiled women are increasingly seen in everyday interactions and are increasingly noticeable in popular media with some magazines being totally devoted to styles of veils and proper relationship management for young Muslims (see Jones, 2016) . Veiling has evolved from a marginal practice of certain socio-demographic segments such as university students to an element of mainstream consumer culture (Heryanto 1999; Jones 2007). In the public mind, the increasing visibility of hijab can be easily observed through the shifts in the way that female civil servants, wives of government officials (Ind: dharma wanita), and female police officers dress. In many government offices, workplace-specific decrees on work uniform now include chapters regulating acceptable uniform-style for veiled female employees. ${ }^{1}$ This is in stark contrast to the norms among civil servants during the Suharto era.

Today, debates still continue whether Islamic law deems veiling as a mandatory (Ind: wajib) or a recommended practice (Sunnah) (see Hamdani, 2008). Veiling is mandatory in some regencies in Indonesia such as those in the province of Aceh, which practise Shariah law (Parker, 2008; Warburton, 2006). However, in most provinces, including Jakarta, there is little overt pressure

\footnotetext{
${ }^{1}$ An example departmental decree on uniform can be found here for employees of the National Civil Service Body (Ind: Badan Kepegawaian Negara): http://www.bkn.go.id/wp-content/uploads/2015/08/PERKA-BKN-NOMOR-11TAHUN-2011-PAKAIAN-SERAGAM-KERJA-BAGI-PNS-DILINGKUNGAN-BKN.pdf
} 
from religious authorities for women to wear the veil and veiling is a relatively free choice. Mandatory veiling in Islamic schools/ tertiary institutions and certain workplaces such as Islamic Banking are noted exceptions in this case as are the occasional cases of mandatory use of hijab by female government workers in some districts or local governments.

Any discussion of veiling in contemporary Indonesia must acknowledge that veiling is not a homogenous practice. It is simplistic to divide women into those who wear a veil and those who don't. Some women may wear a veil only for certain formal occasions; others may wear it on a daily basis. Some wear a long veil with a long skirts that covers their body shape, whereas others wear a 'fashionable' veil matched with trendy jeans or figure-hugging clothes. This point is well emphasized in Nef-Saluz's (2007) anthropological study of students at Gadjah Mada University. She categorized veiling students into three categories. The first category consisted of those women wearing full chadors. This was a relatively small group seen by many of the other students as being very extreme. The second group wore long veils, and long skirts and socks intended to cover the shape of their body. These also would not interact with boys, and practised certain conservative behaviours. ${ }^{2}$ Some of the other students felt that these girls were 'boring' or 'too serious'. The third group, which was quite heterogeneous, was those who wore a 'hijab gaul' or 'trendy veil'. This was the largest group of veiled women and consisted of young women who often combined a head covering with jeans and form-fitting clothes. Their veils were trendy and stylish. The categories were not always strictly defined and students moved from one category to another or wore different types of veils, or changed from being veiled to unveiled for different occasions. However, despite the varied practice of veiling, it is generally agreed that Indonesia has witnessed a rise in the voluntary adoption of veiling since the late 1990 s.

\section{Drivers of veiling in contemporary Indonesia}

As distinct from the popular Western discourses presenting veiling as a symbol of female oppression and fundamentalism (Byng 2010), contemporary studies on veiling in Indonesia underscore a theme of modernity. Brenner (1996) posits that veiling is central to the production of modernity among Muslim women in Java. The idea of veiling as an expression of modernity was continued by Smith-Hefner (2007) who argued that:

“...the new veiling is neither a traditionalist survival nor an antimodernist reaction but rather a complex and sometimes ambiguous effort by young Muslim women to reconcile the opportunities for autonomy and choice offered by modern education with a heightened commitment to the profession of Islam" $(2007, p$. 389)

Others consider veiling as part of modernization and focus on consumerism: veiling is now part of consumer culture. Heryanto (1999) notes veiling and other symbols of Islam are a form of "life styling” associated with modernity and wealth. Here, the young urban Muslim middle-class identify with being modern and cosmopolitan, whilst expressing their piety and identity as a devout Muslim through their consumption and lifestyle:

"In today's Islam in Indonesia, old familiar images have been replaced by new ones. The associations of Islam with rural poverty, religious dogmatism, the Middle East, antiChinese, anti-West sentiments, and fundamentalists seeking to establish an Islamic state

\footnotetext{
${ }^{2}$ Nef-Saluz referred to a respondent with a Chador who regularly attended a Shalafi study group in a particular mosque, did not listen to music, did not watch TV and had generally very low media consumption.
} 
are juxtaposed with new images. Now Islam is also associated with television talk shows...mobile phones and consumption of ketupat [rice cakes] during Ramadhan at McDonald's" (Heryanto 1999:176)

Along this line, Jones $(2007,2010)$ strengthened the proposition that veiling represents a rise in pious consumption: the commodification of Islamic dress symbolises the complex interaction between emerging consumer culture and faith-centred lifestyle in Indonesia. She outlined three interrelated drivers of pious consumption in Indonesia: the rise of the middle-class, the rise of Islamic piety, and the rise of consumption associated with the middle-class. The growing demand for veiling has been met with a bourgeoning industry of Muslim fashion (Ind: baju muslim), catering for all budgets with stores found anywhere from traditional markets to upper class malls, and via online shopping. Indeed, veiling is central to the bourgeoning Islamic pop culture in film, television, books, magazines, and multiple forms of social media (Heryanto, 1999, Heryanto, 2011, Barendregt 2009, Hoesterey and Clark, 2012). A comparative study behind the social psychology of veiling provides further evidence of this argument, suggesting that while veiled women in a Muslim minority setting in India places veiling in the context of a reaffirmation of their cultural identity, veiled women in Indonesia, a Muslim majority country, speaks of veiling in terms of fashion, modesty and convenience (Wagner et al., 2012).

In contrast to the veiling as consumption literature, others have examined veiling in the realm of class, identity, and the collective practice of Islam in the public sphere. Rinaldo (2008) draws upon the practice of veiling among tertiary-educated members of the Prosperous Justice Party (Ind: Partai Keadilan Sejahtera (PKS), an Islamic party). As distinct from other more varied veiling and Islamic clothing styles, the women of PKS notably wear a relatively modest and conservative form of veiling. Rinaldo argued that among these women, the Hijab serves as an expression of collective pious identity. More importantly, it serves as a symbol of a break from the past - from the state gender ideology of the New Order, and from an era of cultural Islam in the past to a new dawn of political Islam in Indonesia ${ }^{3}$ :

"The clothing practices of PKS women contribute to modern habitus not only because they depend on self-discipline and education, but because they represent an orientation toward something new and different. They reference the Middle East but are not an imitation". (2008: 32).

Rinaldo's case study of the women of PKS presents a contrasting landscape to the widespread popularity of veiling in the post- New Order period, beyond the realm of the ideologically driven members of PKS. Hasbullah (1999) noted that in the late 1990s, the widespread redefinition of Islam from ideological/political Islam to cultural Islam has induced Indonesians to engage in more religious activities, including voluntary adoption of the practice of veiling. These variations in the meaning and the drivers of veiling in Indonesia explain why the observed styles and practices are far from homogenous.

\footnotetext{
${ }^{3}$ Here, political Islam refers to organised forces who are seeking to bring about transformative change in State and society where Islamic rule and laws prevails. During the New Order, the idea of Islam as a political ideology had been largely discouraged. However, Islamic cultural, spiritual and intellectual forces continue to flourish. The tagline popularised by the scholar Nurcholis Majid - Islam yes, Islamic parties no - embodies this marked difference between cultural and political Islam (see Ali, 2005).
} 


\section{New veiling}

Outside of Indonesia, recent case studies in other parts of the Muslim world also indicate that veiling is gaining traction among the well-educated middle class; for example, in Cairo (MacLeod, 1992), and in Turkey (Gole, 2003; Sandicky and Ger 2010). In the developing Muslim world, it is plausible that the uptake of veiling serves as an indicator of parallels between modernity and religiosity. As argued by past research on Indonesia outlined in the preceding sub-section, much of this is attributed to the growth of an educated urban middle-class that is also becoming increasingly religious. Such trends run counter to earlier predictions made by secularisation theorists.

Prior to the bourgeoning criticism of secularisation theory (Hadden, 1987; Norris \& Inglehart, 2011; Stark, 1999); past studies in the West have mostly found negative associations between socio-economic status (often measured by education level) and religiosity (Albrecht \& Heaton, 1984). But models of secularisation do not always fit well in the non-Western context (Casanova, 2011),

Using data on Muslims living in Java, Tamney found that education and urbanisation are positively related to established religiosity (measured in the practices of regular prayers, alms-giving and fasting) (1979) and to the role that religion plays in everyday life (functional religiosity) (1980). We note that Tamney's observations in the late 1970s are consistent with the bulk of the literature associating veiling with religiosity among the urban, educated middle class in present-day Indonesia. As noted by Heryanto (2011: 60):

"The conspicuous presence of what can be called "Pop Islam" or "Islamic chic" in the last two or three decades has been a further blow to the already discredited modernist and liberalist theorist. The onward march of modernization has not pushed religions to the margin of social life, to near extinction. Modernity does not necessarily imply or require secularization.”

By highlighting the phenomenon of veiling in Indonesia, our paper speaks to the flourishing literature highlighting the continuous relevance of religion amidst modernity and globalisation (Casanova, 2011, Deeb, 2011, Turner, 20110

\section{APPROACH, DATA, AND METHODS}

\section{Approach}

Our review of research on the uptake of veiling in Indonesia highlights a number of important points. First, the literature points to a consensus that the current popularity of veiling is not due to a revivalism of a historical tradition, nor it is necessarily a proxy of growing Islamic fundamentalism. Rather, veiling is associated with the production of modernity (Brenner, 1996), of collective practice of Islam (Rinaldo, 2008 ), of 'life styling' (Heryanto, 1999), and of 'pious consumption' (Jones, 2010) particularly among the urban middle-class in post-authoritarian Indonesia.

Second, we note that such trends are not specific to Indonesia. The literature is rich with parallel cases of other Muslim-majority countries where veiling has become increasingly fashionable among middle-class women. These discourses around modernity and veiling add to the complexity of the juxtaposed scholarship on secularisation on one hand and the scholarship on radicalisation/fundamentalism in the Muslim world on the other. 
In the light of these findings, we expect that a quantitative exercise on the correlates of veiling would find a positive association between socio-economic status and veiling among young adults in Greater Jakarta. In this paper, we built upon Tamney’s work (1979 and 1980) and use education level as an indicator of an individual's socio-economic status.

\section{Data}

To examine the nature of veiling among young women in urban Indonesia, we use data from the 2010 Greater Jakarta Transition to Adulthood survey. The survey interviewed 3,006 young adults aged between 20 to 34 years randomly sampled from Jakarta as well as the adjoining cities of Bekasi and Tangerang. The survey collected detailed information regarding demographic characteristics of the respondents, including their current education and work situation, their health and well-being, attitudes and values. The survey instrument contained numerous questions designed to measure religious affiliation as well as different dimensions of religiosity. In addition to the survey, face-to-face intensive interviews were conducted with 80 randomly selected men and women from the original sample. The aim of these interviews was to gain additional insights into the lives of the respondents and ask them more in-depth questions about a range of topics including religion and religiosity. Thus, questions around religious practice and attitudes, including veiling were included as a sub-theme in the broader exploration of the respondents' transition to adulthood, and not as core objectives of the study.

In this study, we limit the analytical sample to 1,443 women who were self-reported Muslim. The mean age of women in the sample was 27.4 years old. An overview of other demographic characteristics of the respondents in our analytical sample is shown in Table 1. All percentages reported are weighted to correct for an overrepresentation of women not in the labour force among the sample members compared to the general population of 20-34 year old living in Greater Jakarta in the 2010 Census. The majority of the women in our sample had completed senior high school (43\%). About 18\% had primary school or lower as their highest completed education level, 20\% had junior high school certificates, and $19 \%$ had tertiary-level certificates. Given their age group and residence in Greater Jakarta, the education distribution of our respondents was quite distinct from the general female population in Indonesia. ${ }^{4}$

As mentioned the survey contained a range of questions designed to measure different aspects of religiosity. The first variable we examine, which is our primary variable of interest, is whether the woman wears a veil on a daily basis or not (Ind: Apakah anda sehari-hari memakai Jilbab?). However, we also examine the data for three additional indicators or measures of religiosity. The first can be described as subjective religiosity and is based on a question which asks people to rate their level of religiosity on a scale of 1 to 5, where 1 equals 'not religious at all' and 5 equals 'very religious'. The second one is what we term organizational religiosity and it is a binary variable that indicates whether the person is a member of a religious organisation or not. Finally, personal religiosity measures how often they read religious texts or books, the options being: frequently, sometimes, and never.

\footnotetext{
${ }^{4}$ Published data from the 2010 Population Census suggests that the distribution of highest completed education for all females aged 19-34 were: $34 \%$ had primary school qualification or less, $24 \%$ had junior high school certificates or equivalent, $33 \%$ had senior high school certificates or equivalent, and $9 \%$ had tertiary education certificates. The corresponding distribution for all females aged 19 and above were: 54\%, $16 \%, 22 \%$, and $7 \%$ respectively. The age 19 is used in the official tabulation given that formal schooling age ends at 18. (BPS-Statistics Indonesia. 2013).
} 


\section{Methods}

At the first stage of the analysis, we use bivariate analysis to examine the relationship between wearing a veil and the other measures of religiosity. The aim is to investigate whether or not wearing a veil goes hand in hand with other indicators of religiosity including high self-perceived religiosity, being a member of a religious organization and reading of religious texts. If wearing the hijab is predominantly a religiously-motivated behaviour then we would expect a strong relationship between veiling and the other measures of religiosity. On the other hand, if veiling is motivated by other reasons such as avoiding sexual harassment or to give the appearance of respectability, or as a status symbol, then the relationship between veiling and the other religiosity indicators will be weaker.

In the second stage of the analysis we examine who is most likely to wear a veil using a multivariate approach. Our dependent variable is whether the woman wears a hijab, and is equal to 1 if she does, and 0 if she does not. Probit models are used to examine the effect of several predictors on the likelihood of wearing a hijab. We control several personal characteristics of women that may affect whether or not they wear the hijab including age (in single years), whether the woman is married or not, and her employment status. We also examine the role of parent's religiosity which is grouped into four categories: neither parent is religious or very religious, just the father is religious or very religious, just the mother is religious or very religious, and both parents are religious or very religious. We expect the correlation between parents religiosity and veiling to be moderate. In the contemporary contexts, veiling should be less associated as a marker of religious lineage/elites as it had been in the past (see Dhofier 1980).

However, our primary interest in the multivariate analysis is to examine the effect of socioeconomic status on the likelihood of veiling. We use highest education as a general proxy for a woman's socio economic-status. We add father's education as a control variable but not mother's education since both are highly correlated.

Finally, we use information from the in-depth interviews to examine what women had to say about the reasons for veiling (or not veiling). This points to the limitations of considering veiling as a binary model.

[Table 1 about here]

\section{RESULTS}

\section{Prevalence of veiling and other self-reported measures of religiosity}

The percentage of women who reported wearing a hijab, as well as the distribution for the other measures of religiosity are shown in Table 2 below. Overall, we find that just over one quarter of the women reported that they wore a veil. It is important to note that this percentage could cover a wide range of veiling behaviour, from the woman who wears the veil every time she is out in public or in the presence of a man, to the student who wears the veil while on the university campus but not at other times.

Turning to the other measures of religiosity, we find that few people reported that they were at either extreme when it came to self-assessed level of faith, with less than $1 \%$ stating that they were not religious at all, and only $7 \%$ describing themselves as very religious. The vast majority of respondents described themselves as being in the middle on the subjective religiosity scale, with a score of 3. In terms of organizational religiosity, we find that belonging to a religious organization 
was a minority behaviour, occurring in only $17 \%$ of the sample. In terms of the frequency of reading religious texts, $22 \%$ said that they read them frequently. The majority again however said that they do so only sometimes. Given that no time reference was included in the wording of the question, the answer to this question may be somewhat subjective. ${ }^{5}$ For example one individual may describe their reading of religious texts once a week as 'sometimes', while another person may class that as being 'frequent'.

Finally, if young women's own level of self-perceived faith is compared to their perceptions of their parent's faith, on average, respondents judged that their parents were more religious. For example, only 7 per cent of women said that they themselves were very religious, but 19 per cent felt that their father was very religious, and 21 per cent felt that their mother was very religious. Howev the majority of the very religious respondents said that their parents were also very religious, and almost none reported their parents as not at all religious.

[Table 2 about here]

\section{Relationship between wearing a hijab and other measures of religiosity}

The data above present a picture of a relatively moderate level of religiosity, with few people describing themselves as being overtly non-religious, or very religious. To get a better idea of the relationship between wearing a hijab and the other measures of religiosity, we conducted a series of pairwise cross-tabulations to examine each measure of religiosity against the other. Since all the measures are discrete variables, we used a chi-square test to test whether the two variables were dependent on each other, and an associated Cramer's V to examine the strength of the relationship between each pair of variables. Due to the small number of cases who indicated that they were not at all religious (i.e. 1 on the level of faith scale), these respondents were grouped together with those that indicated they were a 2 on the level of faith scale for the purpose of the chi-square tests.

We find that all of the chi-square tests were significant at $\mathrm{p}<0.001$. Due to space limitations we do not present each cross-tabulation here, however Table 3 below shows the values of Cramer's V for each pairwise relationship. In general, the relationship between each measure of religiosity and the other could be described as 'moderately' strong. The strongest association is between wearing a hijab and the frequency of reading religious texts. For example, while 41 per cent of veiled women reported reading religious texts often, only 16 per cent of unveiled women reported doing the same. Overall women who wore the hijab were more likely to score highly on the other religious measures. However, a small minority of veiled women appeared not to be strongly religious based on these measures. For example, 4 per cent of women who wore a hijab indicated that they were only a 1 or a 2 on the level of faith scale. Similarly, 5 per cent never read religious texts. It is also interesting to note that the indicators of father's and mother's religiosity, while statistically significant, were only weakly related to whether the woman wore the hijab or not.

[Table 3 about here]

The 2010 Greater Jakarta Transition to Adulthood survey also has a separate section on media consumption. While the set of questions on media consumption is placed apart from the section on religiosity in the questionnaire, we could explore whether there are significant differences in the

\footnotetext{
${ }^{5}$ This was a shortcoming in the questionnaire design. The question should have included specific time reference and count intervals for example: how many times did you read the Koran in the last month?.
} 
consumption of religious media and the practice of veiling. In Table 4 below we note the differences in the frequency of consuming religious media (TV, radio, and the Internet) between veiled and unveiled Muslim female respondents were significant at the 5 per cent level. As expected, veiled respondents reported higher frequency of consuming religious media.

[Table 4 about here]

\section{Relationship between wearing a hijab and attitudes}

Tables 5 and 6 outline the relationship between the wearing of hijab and selected attitudinal measures. In general, there were no major differences between women with and without a veil in regards to their world views (Table 5). Differences between veiled and unveiled women are statistically significant for the last two statements but the relationship is only weak. Here, we note that our measures on world views in the survey may be weak when used in a study on veiling. First, a surprisingly large proportion of respondents either agreed or strongly agreed that Indonesia should become an Islamic state. We suspect that a large number of respondents may have misunderstood the question. ${ }^{6}$ Second, the wording in the last two statements suggest that we cannot ascertain whether a respondent was in favour of Western vis-a-vis Middle Eastern/Islamic influence on young people.

[Table 5 about here]

When it comes to political views, we did find a difference between veiled and unveiled women in the likelihood of having voted for an Islamic party in the last election (Table 6). Among women who reported wearing a veil, 14 per cent indicated that they had voted for an Islamic party compared to just 6 per cent of women without a veil. However, the large majority of veiled women did not vote for an Islamic party.

[Table 6 about here]

\section{Multivariate analysis}

Table 7 present the results of our multivariate analysis on the likelihood of veiling. Age was not a significant predictor of veiling. This is likely due to the nature of our sample. With our target population covering a relatively narrow age range, we cannot observe the widely held perception that veiling and religiosity is positively associated with age.

We found no significant difference in the likelihood of veiling between female Muslim respondents who were not married and those who were married at the time of the survey. Our results support what has been widely observed in the literature on contemporary veiling in Indonesia: a) holding all else constant, the likelihood of veiling is highest among students relative to young Muslim women in other activity categories; b) there is a positive relationship between the likelihood of veiling and education level. Figure 1 further depicts how the predicted probability of wearing the veil is higher among tertiary educated Muslim women relative to other Muslim women in our sample. For example, holding age, marital status, and employment status at their mean values ( Model 3), the probability of veiling is $18 \%$ for respondents with a primary school/below education, $17 \%$ for junior high school graduates, $26 \%$ for senior high school graduates, $43 \%$ for those with diplomas, and $47 \%$ for university graduates (bachelor degrees and

\footnotetext{
${ }^{6}$ In the second wave of the Greater Jakarta Transition to Adulthood Survey fielded in 2014, the wording to this question was revised to: 'It is better for Indonesia to adopt Sharia law' but still a majority claimed to agree with this sentiment.
} 
above). In Table 7, we use senior high school graduates as a reference category. Across the five models presented, we found statistically significant differences in the probability of veiling between senior high school graduates and those with post-school qualifications. In general, those at the lower end of the education spectrum have a lower probability of veiling than respondnets with senior high school qualification. However, the difference in this probability is no longer significant once father's education level is added as a control variable (model 5).

There is a very strong relationship between wearing the veil and the education of the respondent's father. As education levels of parents are well below the education levels of the respondents (Table1), those with a highly educated parent are selective of the highest status people. Thus, veiling is not just a result of the respondent's own education; it is influenced further by the respondent's social class as indicated by the education of her father.

[Table 7 about here]

[Figure 1 about here]

\section{Qualitative insights}

Using in-depth interview results of both male and female Muslim respondents, we were also able to garner further insights on the practice of veiling and on the limitation of our statistical approach in exploring the practice of veiling. ${ }^{7}$

First, we found that the narratives on the personally defined boundaries of where one should put on the hijab, on its intermittent practice, motivation, and meaning for different women supports the argument that veiling has different meanings in different contexts. For example, one respondent reported that she only wore the hijab on 'special occasions' such as going to events or meetings at her children's school, or to religious functions. For this respondent, the hijab connotes dressing up which she associates with outfits appropriate for semi-formal and formal occasions, and the rationale of covering up in front of non-mahram ${ }^{8}$ males was not expressed:

"Pengen banget (pakai jilbab), ngeliatnya teduh, sejuk liat mukanya itu. Paling kalo ada, paling ke sekolahan anak saya pake jilbab, kalo ada reuni-reuni, perkumpulan, pengajian pake jilbab, abisnya gerah sih. Namanya di dapur aja pake jilbab panas [I really want to (wear the hijab), it feels so soothing to look at, feels comforting to look at the faces (of ladies wearing the hijab). (I wear the hijab) at least when I go to my kid's schools, to reunions, social gatherings (and) Koran reading groups, because it's so hot. Being in the kitchen you know, it's hot to be wearing the hijab] (Ijah Hadijah, 32, married, junior high school graduate, housewife).

The above quote demonstrates the respondent's perceived association between Hijab and "respectable" outfits for social functions. Here, veiling is expressed as a potential marker of aspiration for women from the lower education background to command public respectability in social functions; perhaps indicating

\footnotetext{
${ }^{7}$ The survey also asked partnered male respondents whether their spouse/romantic partner (Ind: Pacar) wears the veil. In this paper, we have not included male respondents' reports of their partner's characteristics to estimate the prevalence and correlates of veiling. However, we found that qualitative insights by male respondents are valuable to contextualise our quantitative results.

${ }^{8} \mathrm{~A}$ woman's mahram is a person that she is never permitted to marry because of a close blood relationship or a relationship by marriage.
} 
their perception that respectability is something that educated/middle class women would easily attain regardless of their attire.

There was also one respondent whose decision to put on, and later, to take off the hijab had little to do with religion:

"Dulu mah saya pakai jilabab bulan karena panggilan hati. Saya pakai cuma buat nutupin rambut, abisan rambut saya kayak laki-laki, jadinya saya copot [Well, in the past, I did not put on the hijab because my heart was calling. I only put in on to cover my hair, my hair (then) looked like men's (haircut), so now I took it off] (Erni, 33, never married, high school graduate, unemployed)

In contrast, another respondent, a tertiary graduate younger than the two previous respondents, expressed a more religious /spiritual motivation for wearing the veil:

"Waktu SMA... kayaknya ngeliat temen gitu yang makai ya, kayaknya enak gitu ya. Saya kan sering baca-baca buku Islami ya, oh jilbab itu wajib, membaca, tapi kan waktu itu kita masih muda ya, ah entar aja dulu. Katanya kalo pakai jilbab harus gini gini gini, terbersitkan di kita seperti itu. Ehm, tiba-tiba dulu setelah saya selesai ikutan acara di sekolah SMA, rohis, Islam, kiyamul lail juga, sholat malam, saya ngimpi gitu ya, saya dikasih kain, selendang kayak gitu...dikasih sama orang berjilbab putih, suruh ditutup gitu kepala. Cuman waktu itu saya nggak terlalu menghiraukan, karena kan jiwanya masih labil, gitu kan, kita masih labil. Makin lama makin lama kok saya makin kepikiran gitu. Kepikiran kepikiran, saya aktif, kan masih tetep aktif tuh pengajian, itu lagi, yang selalu muncul itu, mimpi-mimpi seperti itu." [I started putting on the Hijab) During high school... when I saw my friends wearing it, it seemed like it was comfortable. I frequently read Islamic books, (then I found out) oh, Hijab is compulsory, but then I was young, so just do it later (I thought). They said that when you wear the hijab, you have to be this, this, this; that was what came to my mind. Um, then all of a sudden, after I finished participating in a high school event, Islamic Study Group, also doing the night prayer, I had a dream that I was given a piece of scarf... given by a person wearing a white veil, telling me to cover my head. But that time I didn't really pay much attention, because I am still emotionally unstable. But as time went on, I kept on thinking about it. It has been on my mind all the time. I am still actively involved in the Koran reading group, and the (similar) dream keeps on coming to me.] (Siti Nuraini, 24, never married, bachelor degree, currently working).

Second, the following examples suggest spatial specificities of veiling between one individual to another, and highlight the limitation of our approach in defining the practice of veiling as a binary choice for Muslim women.

- Respondent A (Ijah - cited above) says that she does not wear the hijab consistently. She wears it on 'special occasions', such as to go to events or meetings at her children's school, to a recent school reunion party, or to a Koran reading group. The respondent does not wear the hijab all the time, citing it being too hot. For respondent A, the hijab connotes dressing up and she associates it with outfits appropriate for semi-formal and formal occasions.

- Respondent B reported that she wears the hijab only when she goes out of the house, or to be precise, when she goes out from the fence bordering her front yard. She only needs to reach out from her terrace to buy vegetables from a cart vendor who daily visits her neighbourbood. On such occasions, she does not put on her veil. 
The in-depth interviews above suggest that, among veiled respondents, their decision when to put on the veil was not always dependent upon whether or not they would be in a situation where they would encounter male non-mahrams (i.e a male for whom the woman is not forbidden to marry/ a male is not a close relative). This runs counter to the supposed religious mandate that veiling must be observed by women in all situations where a male non-mahram is present (see Hamdani, 2008: 109).

All in all, the in-depth interviews canvassed varying opinions whether wearing the hijab is a religious obligation for Muslim women or not. Some respondents suggest that it is, some said that it is a highly commendable practice (Sunnah), and then there were others that said that it is compulsory, but it really is up to the individual woman to decide. Further, given the small size of our sample, it was impossible to infer whether there are links between the rising popularity of the hijab to a general rise in the level of religiosity among young Muslims in Greater Jakarta. While we did identify cases where veiling is closely linked to religiosity, there were others who expressed veiling as part of social aspiration, and./or its increasing adoption as a form of formal wear.

\section{CONCLUSION}

While we acknowledge that our approach to understand the nature of veiling is limited by the complexities and variations in the meaning, drivers, and contexts of veiling, we believe that our paper contributes to the literature on the uptake of veiling in post-New Order Indonesia in a number of ways.

First, our approach provides self-reported behaviour and attitudes from a representative sample of young adults in Greater Jakarta. We estimate that 1 in 4 young Muslim women in 2010 were involved in some form of veiling in the capital metropolis. In a Muslim majority county context, some may argued that this is relatively low, but this result should be interpreted through a comparative lens, contrasting it to very limited practice by similarly aged women during the New Order. Our results are in line with the literature showing that - from an Islamic law perspective the contemporary status of veiling in Indonesia is one that is riddled with ambiguity.

Second, we test the hypothesis that the rise in veiling signifies a growth of personal/internalised religious idenity among young adults in Jakarta. We found that there is a moderately strong relationship between veiling and various measures of religiosity, including subjective religiosity, reported frequency of reading religious texts, and reported consumption of religious media at the individual level. Such findings offer quantitative support for the bourgeoning scholarship on rise of consumption of 'piety' among the middle class in democratising Indonesia (e.g. Fealy, 2008).

Third, we test the view that the increased uptake of veiling represents a society-wide trend towards anti-West sentiments. We found weak relationships between veiling and such social attitudes/ We underline that we do not have satisfactory measures to establish whether the uptake of veiling is indicative of anti-West sentiments among our respondents. Still, we found positive associations between veiling and voting preferences towards Islamic-based political parties.

Fourth, the insights from the multivariate analysis support existing knowledge from the predominantly qualitative scholarship on veiling in Indonesia. We note that our results indicated that marital status is not a significant predictor of veiling. While this may be the case, our qualitative insights suggest that transition to marriage may encourage young women to put on the 
veil, often at the request of their husbands and families. Among the middle-class, veiling may also be regularly practised following the pilgrimage to Mecca (Umra/ Hajj).

Using multivariate analysis, we test the hypothesis whether there is a positive association between veiling and being middle-class. Our findings support the assertion that there is an important class dimension in the uptake of veiling in Indonesia. Previous qualitative studies on veiling suggest that regardless of whether veiling is treated as a symbol of political Islam (PKS - Rinaldo, 2008), or whether it signifies increasing pious consumption and 'lifestyling' (Heryanto, 1999; Hasbullah, 1999; Jones, 2007, 2010), the likelihood of veiling is higher among the educated segment of the population. Our findings provide quantitative evidence of a strong association between respondent's own education and the likelihood of veiling. We especially observed this positive association between class and veiling when we incorporated father's education as a proxy for class. Overall, these findings support the hypothesis that veiling represents a display of public respectability, modesty, and proper behaviour for middle/upper class women. This is supported by the emergence of Islamic fashion/styles, by the wearing of the hijab by female Ministers, parliamentarians and senior public servants. The finding that veiling is particularly prevalent among students is also consistent with other qualitative studies on veiling that had been conducted within universities (e.g. Smith-Hefner, 1996.2007; Nef-Saluz 2007). We speculate that while 'class' and the associated pious consumption are one important part of the story behind veiling, conformity is another important sub-theme. Schooling produces an environment for ideas, be it ideological or fashion, to spread easily among peers. In such settings, the practice may be less an expression of true piety than a manifestation of the formation of cliques and peer groups so typical of school settings around the world.

In Greater Jakarta, the emergence of elite Islamic high schools is an important factor in class history in Jakarta. While we cannot distinguish whether a respondent had attended a Madrasah or an elite Islamic private high school, our data did suggest that attending an Islamic school at age 16 is positively associated with veiling. In the mid-1990s, a number of general (public) high schools started the practice of requiring students to wear appropriate religious outfits on Fridays, including the hijab for Muslim girls. ${ }^{9}$

The popularity of veiling among female public servants in Greater Jakarta provides another avenue for research to gauge peer effects on veiling in formal institutions. In the context of the rise of global Islam, future research could also test the relationship between veiling and young women' aspirations to be modern and cosmopolitan in Greater Jakarta.

However, we recognize the limitation of our analysis due to the cross-sectional nature of the dataset. While our analysis only showed a weak relationship between veiling and social views, we note that much has changed in the years since we collected this data. A second wave of the Greater Jakarta Transition to Adulthood survey was fielded in 2014. Our preliminary analysis identified 841 Muslim female who participated in both wave 1 and wave 2 of our study. We note that among these respondents, the rate of veiling had climbed from 25 per cent in 2010 to 37 per cent in 2014. About 18 per cent of the respondents, who reported that they did not wear the veil daily in 2010, reported that they were veiled in 2014. Less than 6 per cent of veiled respondents in 2010 reported that they no longer put on the veil on a daily basis in 2014. At this stage, we cannot conclude whether the increased prevalence is attributed to the fact these women had grown older, had a

\footnotetext{
${ }^{9}$ This practice is still continuing in public schools.
} 
higher level of education than in 2010, had commenced working since first interviewed in 2010, or whether it was due to broader societal factors.

It is tempting to speculate a link between the rise of veiling and the renewed rigour for conservative Islam as evident in the polarizing campaigns for the 2014 Presidential Election (see Kwok, 2014). This brings up another weakness from our survey in that we cannot identify the distinctive style of veiling among our respondents. For example, we did not record how many veiled respondents are wearing long veils over loose garments and how many would be happy to wear a head covering and jeans. The survey also did not include direct questions around motivations to veil/not to veil. Only a small number of respondents from the qualitative part of the study expressed that veiling was a result of a spiritual calling, or that it was solely motivated by religious mandate. But, given the small qualitative sample, we cannot make any conclusive statements on the correlation between the rise of political Islam and veiling. Future research on this topic may benefit from a mixed methods approach, with research questions detailing the various styles, attitudes, motivations, and class contexts around veiling.

On one hand, rather than pointing to the rise of conservative Islam per se, our findings are supportive of the narrative around the middle-class 'life styling' and consumptive aspects of veiling trends in urban Indonesia. On the other, the growing debates about what is proper/the right way to veil, and what is not, is indicative of mounting tensions in many other aspects pertaining to the practice of Islam in the country. For example, there have been increasing calls for the adoption of the more conservative Jilbab Syar' $i$ - loosely translated as the 'proper' Islamic way to cover up for women - as distinct to a more casual/nonchalant style of veiling where the outlines of the woman's body shape is still noticeable. ${ }^{10}$ The work of Nisa (2012) and Rinaldo (2013) had explored how these different styling of the hijab is linked to political identity and/or political party affiliations. Further work needs to be done to examine the extent to which divergent veiling practices relate to the fragmented influences of the many sources of Islamic authority across the many layers of Indonesian society.

\section{REFERENCES}

Albrecht, S. L., \& Heaton, T. B. (1984). Secularization, Higher Education, and Religiosity. Review of Religious Research, 26(1), 43-58. doi: 10.2307/3511041

Ali, M. (2005). The rise of the Liberal Islam Network (JIL) in contemporary Indonesia. American Journal of Islamic Social Sciences, 22(1), 1-27.

Amrullah, E. F. (2008). Indonesian Muslim Fashion Styles \& Designs. ISIM Review, 22, 22.

Barendregt, B. A. (2009). Mobile Religiosity in Indonesia: Mobilized Islam, Islamized Mobility and the Potential of Islamic Techno Nationalism. Living the Information Society in Asia, 73-92.

BPS-Statistics Indonesia. (2013). Population Census 2010. http://sp2010.bps.go.id/

Brenner, S. (1996). Reconstructing self and society: Javanese Muslim women and "the veil". American Ethnologist, 23(4), 673-697. doi: 10.1525/ae.1996.23.4.02a00010

\footnotetext{
${ }^{10}$ See for example media article: Affen Heyder (2015) Mengapa jilbab syar'I merebak dan menjadi trend? [Why did the jilbab syar'I rose in popularity?

]http://www.bbc.com/indonesia/majalah/2015/06/150621_magazine_bisnis_trendmodejilbab
} 
Byng, M. D. (2010). Symbolically Muslim: Media, Hijab, and the West. Critical Sociology, 36(1), 109-129. doi: 10.1177/0896920509347143

Candraningrum, D. (2013). Negotiating Women's Veiling: Politics and Sexuality in Contemporary Indonesia. IRASEC Occasional Paper No.22. Bangkok.

Deeb, L. (2011). An enchanted modern: Gender and public piety in Shi'i Lebanon. Princeton University Press.

Dhofier, Z. (1980). Kinship and Marriage among the Javanese Kyai. Indonesia, (29), 47-58.

Fealy, G. (2008). Consuming Islam: Commodified religion and aspirational pietism in contemporary Indonesia. Expressing Islam: Religious life and politics in Indonesia, 80-94.

Geertz, C. (1976). The religion of Java: University of Chicago Press.

Göle, N. (2003). The voluntary adoption of Islamic stigma symbols. Social Research, 70(3): 809828

Hadden, J. K. (1987). Toward Desacralizing Secularization Theory. Social Forces, 65(3), 587611. doi: 10.1093/sf/65.3.587

Hamdani, D. (2008). The Quest for Indonesian Islam: Contestation and Consensus Concerning Veiling. The Australian National University, Canberra.

Hasan, N. (2009). The making of public Islam: piety, agency, and commodification on the landscape of the Indonesian public sphere. Contemporary Islam, 3(3), 229.

Hasbullah, M. (1999). The making of hegemony: Cultural presentations of the Muslim middle class in Indonesian New Order period. PhD Thesis: The Australian National University.

Heryanto, A. (1999). Identity politics of Indonesia's new rich. Culture and privilege in capitalist Asia, 159.

Heryanto, A. (2008). Popular culture in Indonesia: fluid identities in post-authoritarian politics: Routledge.

Heryanto, A. (2011). Upgraded piety and Pleasure: The new middle class and Islam in Indonesian popular culture. In Wientraub. A.N. (ed). Islam and popular culture in Indonesia and Malaysia, 60-82, Routledge.

Hoesterey, J. B., \& Clark, M. (2012). Film Islami: Gender, piety and pop culture in postauthoritarian Indonesia. Asian Studies Review, 36(2), 207-226.

Ida, R. (2008). Muslim women and contemporary veiling in Indonesian sinetron, pp. 47-67 in Blackburn, S., Smith, B.J, and S, Syamsiyatun (Eds) Indonesian Islam in a new era: How women negotiate their Muslim Identities. Monash Unveristy Press: Melbourne, Australia.

Jefferies, L. (2011). The Rise of the Hijabisasi in Indonesia: Implications for Christian Witness Missiology: An International Review 39(2): 227-238,

Jones, C. (2007). Fashion and Faith in Urban Indonesia. Fashion Theory: The Journal of Dress, Body \& Culture, 11(2-3), 211-231.

Jones, C. (2010). Materializing piety: Gendered anxieties about faithful consumption in contemporary urban Indonesia. American Ethnologist, 37(4), 617-637.

Jones, C. (2016). Images of desire: Creating virtue and value in an Indonesian Islamic lifestyle magazine. In Islam, Marketing and Consumption (pp. 120-140).

Kwok, Y. (2014) The World's Most Populous Muslim Nation Is About to Decide Its Political Future. Time, July 8 2014. http://time.com/2964702/indonesia-election-2014-jokowidodo-jokowi-prabowo-subianto/ 
MacLeod, A. E. (1992). Hegemonic Relations and Gender Resistance: The New Veiling as Accommodating Protest in Cairo. Signs, 17(3), 533-557. doi: 10.2307/3174622

Nef-Saluz, C. (2007). Islamic Pop culture in Indonesia: An anthropological field study on veiling practices among students in Gadjah Mada University of Yogyakarta. Arbeitsblatt Nr. 41, Institut für Sozialanthropologie, Universität Bern, Bern 2007

Nisa, E. F. (2012). Embodied faith: agency and obedience among face-veiled university students in Indonesia. The Asia Pacific Journal of Anthropology, 13(4), 366-381.

Norris, P., \& Inglehart, R. (2011). Sacred and secular: Religion and politics worldwide: Cambridge University Press.

Parker, L. (2008). To Cover the Aurat: Veiling, Sexual Morality and Agency among the Muslim Minangkabau, Indonesia Intersections: Gender and Sexuality in Asia and the Pacific, 16.

Rinaldo, R. (2008). Muslim women, middle class habitus, and modernity in Indonesia. Contemporary Islam, 2(1), 23-39.

Rinaldo, R. (2013). Mobilizing piety: Islam and feminism in Indonesia. Oxford University Press.

Sandicki, Ö and Ger, G. (2010). Veiling in style: How does a stigmatized practice become fashionable? Journal of Consumer Research, 37(1):15-36

Smith-Hefner, N. J. (2007). Javanese Women and the Veil in Post-Soeharto Indonesia. The Journal of Asian Studies, 66(02), 389-420. doi: doi:10.1017/S0021911807000575

Stark, R. (1999). Secularization, R.I.P. Sociology of Religion, 60(3), 249-273. doi: $10.2307 / 3711936$

Turner, B. S. (2011). Religion and modern society: Citizenship, secularisation and the state. Cambridge University Press.

Wagner, W., Sen, R., Permanadeli, R., \& Howarth, C. S. (2012). The veil and Muslim women's identity: Cultural pressures and resistance to stereotyping. Culture \& Psychology, 18(4), 521-541. doi: 10.1177/1354067x12456713

Warburton, E. (2006). Private Choice or Public Obligation? , The University of Sydney. 
Table 1. Sample statistics

\begin{tabular}{lcc}
\hline & N (unweighted) & Percentage (weighted) \\
\hline Marital status & & 32 \\
Not currently married & 452 & 68 \\
Married & 986 & \\
Highest education level & & 18 \\
Primary School or below & 263 & 20 \\
Junior secondary school & 283 & 43 \\
Senior secondary school & 621 & 9 \\
Certificate qualification & 133 & 10 \\
University degree & 141 & \\
Father's education level & & 46 \\
Primary School or below & 683 & 15 \\
Junior secondary school & 197 & 24 \\
Senior secondary school & 341 & 4 \\
Certificate qualification & 51 & 4 \\
University degree & 58 & 7 \\
Don't know & 11 & \\
Employment status & & 48 \\
Employed & 659 & 7 \\
Unemployed & 82 & 4 \\
Studying & 63 & 42 \\
Not in the labour force - other & 635 & \\
\hline
\end{tabular}

Source: 2010 Greater Jakarta Transition to Adulthood Survey, note that missing cases are not reported. 


\section{Table 2. Measures of religiosity}

Own religiosity

$\%$ (weighted)

Do you wear a hijab on a daily basis? $(N=1,443)$

Yes

No

On a scale of $1-5$, how religious are you? $(N=1,438)$

1 [not religious at all]

2

3

7

4

5 [very religious]

Don't know/can't answer

Are you a member of any religious organization? $(N=1,442)$

Yes

No

How frequently do you read religious texts? $(N=1,442)$

Frequently

Sometimes

60

Never

18

\section{Parents' religiosity}

On a scale of $1-5$, how was/is your father? $(N=1,441)$

1 [not religious at all]

2

3

4

5 [very religious]

Don't know/can't answer

On a scale of $1-5$, how was/is your mother? $(N=1,441)$

$\begin{array}{lc}1 \text { [not religious at all] } & 1 \\ 2 & 4 \\ 3 & 41 \\ 4 & 26 \\ 5 \text { [very religious] } & 21 \\ \text { Don't know/can't answer } & 7\end{array}$


Table 3. Relationship between wearing a hijab and other measures of religiosity

\begin{tabular}{|l|c|c|c|c|c|}
\hline & $\begin{array}{c}\text { Subjective } \\
\text { religiosity }\end{array}$ & $\begin{array}{c}\text { Member of } \\
\text { religious } \\
\text { organization }\end{array}$ & $\begin{array}{c}\text { Frequency of } \\
\text { reading } \\
\text { religious texts }\end{array}$ & $\begin{array}{c}\text { Father's } \\
\text { religiosity }\end{array}$ & $\begin{array}{c}\text { Mother's } \\
\text { religiosity }\end{array}$ \\
\hline Wear a hijab daily & $\mathbf{0 . 2 2}$ & $\mathbf{0 . 2 1}$ & $\mathbf{0 . 3 0}$ & $\mathbf{0 . 1 1}$ & $\mathbf{0 . 0 9}$ \\
\hline Subjective religiosity & & 0.16 & 0.21 & 0.28 & 0.32 \\
\hline $\begin{array}{l}\text { Member of religious } \\
\text { organization }\end{array}$ & & & 0.26 & 0.10 & 0.09 \\
\hline $\begin{array}{l}\text { Frequency of reading } \\
\text { religious texts }\end{array}$ & & & & 0.16 & 0.16 \\
\hline Father's religiosity & & & & & 0.50 \\
\hline
\end{tabular}

Source: 2010 Greater Jakarta Transition to Adulthood Survey 
Table 4. Consumption of religious media

\begin{tabular}{lcccccc} 
& \multicolumn{2}{c}{$\begin{array}{c}\text { Watch religious } \\
\text { programs on television }\end{array}$} & \multicolumn{2}{c}{$\begin{array}{c}\text { Listen to religious } \\
\text { programs on radio }\end{array}$} & \multicolumn{2}{c}{$\begin{array}{c}\text { Browse religious } \\
\text { websites on internet }\end{array}$} \\
& Veiled & Unveiled & Veiled & Unveiled & Veiled & Unveiled \\
\hline Daily & 31 & 21 & 5 & 4 & 4 & 1 \\
Several times a week & 26 & 26 & 14 & 9 & 19 & 6 \\
Once a week & 19 & 16 & 7 & 8 & 12 & 7 \\
Less than once a week & 14 & 20 & 19 & 16 & 24 & 20 \\
Never & 10 & 17 & 54 & 64 & 41 & 66 \\
\hline Total & 100 & 100 & 100 & 100 & 100 & 100 \\
\hline Source: 2010 Greater Jakarta Transition to Adulthood Survey. & The table present column percentages. Differences \\
between veiled and unveiled women significant at $\mathrm{p}<0.05$, tested for consumption of all media types using chi-square.
\end{tabular}


Table 5. Percentage of women who agree with the following statements, by veiling status

\begin{tabular}{lcccccc}
\hline & $\begin{array}{c}\text { It is better for } \\
\text { Indonesia to be an } \\
\text { Islamic state }\end{array}$ & $\begin{array}{c}\text { Western culture has a very large } \\
\text { influence on Indonesia's young } \\
\text { generations }\end{array}$ & $\begin{array}{c}\text { Middle Eastern culture has a very } \\
\text { large influence on Indonesia's } \\
\text { young generations }\end{array}$ \\
\hline \hline Strongly agree & 10 & 7 & 11 & Unveiled & Veiled & Unveiled \\
Agree & 47 & 45 & 74 & 69 & 3 & 3 \\
Mixed & 12 & 14 & 5 & 6 & 51 & 40 \\
Disagree & 28 & 29 & 7 & 9 & 12 & 24 \\
Strongly disagree & 1 & 1 & 0 & 1 & 1 & 0 \\
Don't know & 2 & 4 & 2 & 8 & 5 & 13 \\
\hline Total & 100 & 100 & 100 & 100 & 100 & 100 \\
\hline Source: 2010 Greater Jakarta Transition to Adulthood Survey. The table present column percentages.
\end{tabular}


Table 6. Party voted in the last General Election (2009)

\begin{tabular}{lcc} 
& Veiled & Unveiled \\
\hline \hline Non-Islamic party & 57 & 67 \\
Islamic party & 14 & 6 \\
No answer/did not vote & 29 & 27 \\
\hline Total & 100 & 100 \\
\hline
\end{tabular}

Source: 2010 Greater Jakarta Transition to Adulthood Survey. The table present column percentages. Difference is significant using a chi-square test at $\mathrm{p}<0.05$ (Cranmer's V 0.15) 
Table 7 Predictors of veiling among 20-34 year old Muslim women, Greater Jakarta, 2010

\begin{tabular}{lccccc}
\hline & Model 1 & Model 2 & Model 3 & Model 4 & Model 5 \\
\hline \hline Age & 0.01 & 0.01 & 0.02 & 0.02 & 0.01
\end{tabular}

\section{Marital status}

Not married (ref)

Married

$\begin{array}{lllll}-0.05 & 0.12 & 0.13 & 0.15 & 0.12\end{array}$

Highest education level

Primary school or below

$\begin{array}{llll}-0.32 * * * & -0.29 * * * & -0.27 * * & -0.02 \\ -0.34 * * * & -0.31 * * * & -0.29 * * * & -0.19 \\ & & & \\ & & & \\ 0.41 * * * & 0.46 * * * & 0.45 * * * & 0.36 * * * \\ 0.51 * * * & 0.57 * * * & 0.55 * * * & 0.37 * *\end{array}$

Junior secondary school

Senior secondary school (ref)

Certificate

University

\section{Employment status}

Employed

Unemployed

Student

Not in the labour force - other

$\begin{array}{ccc}-0.19 & -0.22 & -0.18 \\ 0.54 * * * & 0.53^{* * *} & 0.63^{* * *} \\ 0.04 & 0.02 & 0.03\end{array}$

\section{Parent's religiosity}

Neither parent religious or very religious

Father religious or very religious

0.05

Mother religious or very religious

$-0.16$

Both parents religious or very religious

$0.20 * *$

\section{Father's education level}

Primary school or below (ref)

Unknown

Junior secondary school

Senior secondary school

Post-secondary qualification

Constant $\begin{array}{lllll}-0.96 * * * & -0.98^{* * *} & -1.19 * * * & -1.23^{* * *} & -1.18^{* * *}\end{array}$

Source: 2010 Greater Jakarta Transition to Adulthood Survey. Results of probit models. $\mathrm{N}=1,443$. 


\section{University Library}

\section{- M M I N E R VA A gateway to Melbourne's research publications}

Minerva Access is the Institutional Repository of The University of Melbourne

Author/s:

Utomo, A;Reimondos, A;McDonald, P;Utomo, I;Hull, T

Title:

Who Wears the Hijab? Predictors of Veiling in Greater Jakarta

Date:

2018-12-01

Citation:

Utomo, A., Reimondos, A., McDonald, P., Utomo, I. \& Hull, T. (2018). Who Wears the Hijab? Predictors of Veiling in Greater Jakarta. Review of Religious Research, 60 (4), pp.477-501. https://doi.org/10.1007/s13644-018-0345-6.

Persistent Link:

http://hdl.handle.net/11343/253858 